\title{
Berberis vulgaris root extract alleviates the adverse effects of heat stress via modulating hepatic nuclear transcription factors in quails
}

\author{
Kazim Sahin ${ }^{1 *}$, Cemal Orhan ${ }^{1}$, Mehmet Tuzcu $^{2}$, Maria H. Borawska ${ }^{3}$, Jakub Jabłonski ${ }^{4}$, \\ Osman Guler ${ }^{5}$, Nurhan Sahin ${ }^{1}$ and Armagan Hayirli ${ }^{6}$ \\ ${ }^{1}$ Department of Animal Nutrition, Faculty of Veterinary Medicine, Firat University, Elazig 23119, Turkey \\ ${ }^{2}$ Department of Biology, Faculty of Science, Firat University, Elazig, Turkey \\ ${ }^{3}$ Department of Bromatology, Medical University, Bialystok, Poland \\ ${ }^{4}$ Department of Toxicology, Medical University, Bialystok, Poland \\ ${ }^{5}$ Department of Toxicology, Institute of Veterinary Control and Research, Elazig, Turkey \\ ${ }^{6}$ Department of Animal Nutrition, Faculty of Veterinary Medicine, Atatürk University, Erzurum, Turkey \\ (Submitted 9 May 2012 - Final revision received 19 October 2012 - Accepted 22 October 2012 - First published online 14 January 2013)
}

\section{Abstract}

To evaluate the action mode of Berberis vulgaris root extract in the alleviation of oxidative stress, female Japanese quails ( $n$ 180, aged 5 weeks) were reared, either at $22^{\circ} \mathrm{C}$ for $24 \mathrm{~h} / \mathrm{d}$ (thermoneutral, TN) or $34^{\circ} \mathrm{C}$ for $8 \mathrm{~h} / \mathrm{d}$ (heat stress, HS), and fed one of three diets: diets containing 0, 100 or $200 \mathrm{mg}$ of B. vulgaris root extract per $\mathrm{kg}$ for 12 weeks. Exposure to HS depressed feed intake by $8.5 \%$ and egg production by $12 \cdot 1 \%$, increased hepatic malondialdehyde (MDA) level by $98.0 \%$ and decreased hepatic superoxide dismutase, catalase and glutathione peroxidase activities by $23.5,35 \cdot 4$ and $55.7 \%$, respectively $(P<0.001$ for all). There were also aggravations in expressions of hepatic NF- $\mathrm{kB}$ and heat-shock protein 70 (HSP70) by 42 and 43\%, respectively and suppressions in expressions of nuclear factor (erythroid-derived 2)-like 2 (Nrf2) and haeme-oxygenase 1 (HO-1) by 57 and 61\%, respectively, in heat-stressed quails $(P<0 \cdot 001$ for all). As supplemental B. vulgaris extract increased, there were linear increases in performance parameters, activities of antioxidant enzymes and hepatic Nrf2 and HO-1 expressions $(P<0.001$ for all) and linear decreases in hepatic MDA level and NF- $\mathrm{KB}$ and HSP70 expressions at a greater extent in quails reared under TN condition and those reared under HS condition. In conclusion, dietary supplementation of B. vulgaris root extract to quails reduces the detrimental effects of oxidative stress and lipid peroxidation resulting from HS via activating the host defence system at the cellular level.

Key words: Berberis vulgaris: Oxidative stress: Biomarkers: Defence system: Nuclear transcription factors: Heat stress

Heat stress (HS) adversely affects survival ${ }^{(1)}$, performance ${ }^{(2,3)}$ and product quality $^{(3)}$ in poultry. Moreover, HS causes oxidative stress, reflected by an increased production of reactive oxygen molecules ${ }^{(4)}$ and decreased concentrations of serum vitamins ${ }^{(5)}$ and minerals ${ }^{(6)}$ that play a role in the defence system. Oxidative stress impairs cell membrane and mitochondrial integrity ${ }^{(7)}$ and causes cell damage through lipid peroxidation ${ }^{(4)}$, which can be minimised by supplementation of antioxidant vitamins ${ }^{(8,9)}$ or natural substances that possess antioxidant potential ${ }^{(10,11)}$.

Berberis vulgaris L. (Barberry L. family Berberidaceae) is grown in Europe and Asia and its various parts (i.e. root, bark, leaf and fruit) are used in traditional medicine ${ }^{(12)}$. B. vulgaris extract exerts numerous biological effects that are pertinent to human medicine, which include antioxidant $^{(13)}$, anti-inflammatory ${ }^{(14,15)}$, antimicrobial ${ }^{(16)}$, antipyretic $^{(12)}$, antipruritic ${ }^{(12)}$, antiurolithic ${ }^{(17)}$, anticonvulsant ${ }^{(18)}$ and antiarrhythmic ${ }^{(19)}$ activities. The antioxidant effect of B. vulgaris extract is attributed to possessing high reductive powers to quench singlet molecular oxygen and peroxyl radicals ${ }^{(13)}$. The root of $B$. vulgaris is usually used for treating a variety of ailments such as diabetes, stomach, liver and kidney discomfort ${ }^{(16,20)}$. The predominant active compound in the plant is berberine, one of isoquinoline alkaloids ${ }^{(12,21)}$.

Transcription factors are key cellular components that control gene expression in response to biological and environmental stimuli ${ }^{(22)}$. NF- $\kappa \mathrm{B}$ is a pleiotropic transcription factor present in almost all cell types, responsible for controlling

Abbreviations: CAT, catalase; GSH-Px, glutathione peroxidase; HO-1, haeme-oxygenase 1; HS, heat stress; HSP, heat shock protein; MDA, malondialdehyde; Nrf2, nuclear factor (erythroid-derived 2)-like 2; SOD, superoxide dismutase; TN, thermoneutral.

*Corresponding author: Professor K. Sahin, fax +90 424238 8173, email nsahinkm@yahoo.com 
DNA transcription and involved in cellular responses to a number of stimuli including free radicals ${ }^{(23)}$. This complex protein acts as the first responder because it is normally present in the cytosol in an inactive form and enters the nucleus in response to a stimulus in order to activate the expression of specific genes ${ }^{(23,24)}$. Heat shock proteins (HSP), known as stress proteins, are a group of proteins that are present in all cells and expressed at high levels when cells are exposed to high or low temperature or other stressors ${ }^{(25,26)}$. HSP play roles in protein folding and unfolding, protein assembling and disassembling and protein translocation ${ }^{(27,28)}$.

Nuclear factor (erythroid-derived 2)-like 2 (Nrf2), another transcription factor, is known as a master regulator of the antioxidant response. It is bound to another protein called Kelch-like ECH (eroyl CoA hydratase)-associated protein 1 in the cytosol ${ }^{(29)}$. Disruption of cysteine residues in Kelch-like ECH-associated protein 1 due to oxidative stress results in accumulation of $\mathrm{Nrf} 2$ in the cytosol $^{(30)}$. Unbound Nrf2 is then translocated into the nucleus, where its binds to the antioxidant response element in the promoter region of many antioxidative genes to initiate their transcriptions ${ }^{(31)}$.

Recently, active components from herbal plants have been explored as possible antioxidants in poultry ${ }^{(32)}$. In a previous experiment, Kermanshahi \& Riasi ${ }^{(33)}$ demonstrated that the addition of dried B. vulgaris fruit to the diet of laying hens improved some blood and egg quality parameters that may have merit for the animal's well-being. Antioxidants are shown to modulate the transcription system ${ }^{(34,35)}$. However, the role of $B$. vulgaris root extract as an antioxidant against HS in poultry has not been investigated. The present experiment was performed to elucidate the mechanism by which supplemental B. vulgaris root extract alleviates performance and oxidative stress in Japanese quails (Coturnix coturnix japonica) exposed to HS.

\section{Materials and methods}

\section{Plant material and extraction}

The plant samples (root of B. vulgaris) were collected during the spring season of 2009 from a forest near Białystok, Poland. After crushing and drying, the samples $(50 \mathrm{~g})$ were subjected to extraction with water and methanol in Soxhlet apparatus for $32 \mathrm{~h}$. The extract was concentrated to dryness under vacuum at $40^{\circ} \mathrm{C}$. The extraction efficiency was 14.9 (SD 0.6 ) and $10.5(\mathrm{SD} 0.7) \%(\mathrm{w} / \mathrm{w})$, respectively, with water and methanol.

\section{GC/MS analysis conditions}

B. vulgaris root extract was assayed using a Perkin Elmer Clarus 680 gas chromatograph (Perkin Elmer Inc.) with a Clarus $600 \mathrm{~S}$ mass spectrometer (Perkin Elmer Inc.). The separation of the analyte was performed on an Elite $5 \mathrm{MS} 30 \mathrm{~m} / 0.25 \mathrm{~mm}$ column (Perkin Elmer Inc.) at the programmed thermostat temperature of $-80^{\circ} \mathrm{C}$ at start-up, followed by increments of $5^{\circ} \mathrm{C} / \mathrm{min}$ up to $320^{\circ} \mathrm{C}$ and isothermally for $22 \mathrm{~min}$. The total time of analysis was $70 \mathrm{~min}$. The injector temperature was $220^{\circ} \mathrm{C}$ and the flow of the carrier gas $1 \mathrm{ml} / \mathrm{min}$. A split of $20 \mathrm{ml} / \mathrm{min}$ was applied. Electron ionisation with $70 \mathrm{eV}$ was used in the spectrometer. The temperatures of the transfer line and the ion source were 240 and $200^{\circ} \mathrm{C}$, respectively. The retrieved signals were identified using the National Institute of Standards and Technology mass spectra library. Signals with height three times larger than the background noises were assessed. Due to low content, berberine was identified using the selected ion research method for ions characteristic with masses of 339-164 and 337-321 m/s.

\section{Evaluation of antioxidant activity and total phenolic content}

Antioxidant activity of $B$. vulgaris root extract was determined as described by Velázquez et $a l{ }^{(36)}$. Briefly, $1.5 \mathrm{ml}$ of a solution of 2,2-diphenyl-1-picrylhydrazyl were added to $0.75 \mathrm{ml}$ of various concentrations of each sample solution ranging from 3.9 to $500 \mu \mathrm{g} / \mathrm{ml}$. The solution of 2,2-diphenyl-1-picrylhydrazyl in methanol $(20 \mathrm{mg} / \mathrm{l})$ was prepared daily before UV measurements. The mixtures were kept in the dark for $15 \mathrm{~min}$ at room temperature and the decrease in absorbance was measured at $517 \mathrm{~nm}$ against a blank consisting of a $1.5 \mathrm{ml}$ of methanol and $0.75 \mathrm{ml}$ of extract solution. Quercetin and gallic acid were used as positive controls. These were converted to percentage 2,2-diphenyl-1-picrylhydrazyl radical scavenging ${ }^{(37)}$. The half-maximal inhibitory concentration value of each extract was determined graphically and all tests were performed in triplicate. A lower half-maximal inhibitory concentration value indicates stronger antioxidant activity.

Total phenolic content was determined using the FolinCiocalteu colorimetric method; the results were expressed as $\mathrm{mg}$ of gallic acid equivalents per $\mathrm{g}$ of extract ${ }^{(38)}$.

\section{Animals, diets and experimental design}

A total of 180, 5-week-old female Japanese quails (C. coturnix japonica) were used in accordance with animal welfare regulations at the Veterinary Control and Research Institute of Elazig, Turkey. All procedures involving birds were approved by the Institutional Animal Care and Use Committee at the Institute of Veterinary Research, Elazig, Turkey (approval code: 2011/5-1). The quails were kept in temperature-controlled rooms at either $22^{\circ} \mathrm{C}$ for $24 \mathrm{~h} / \mathrm{d}$ (thermoneutral, $\mathrm{TN})$ or $34^{\circ} \mathrm{C}$ for $8 \mathrm{~h}(09.00$ and 17.00 hours $)$ followed by $22^{\circ} \mathrm{C}$ for $16 \mathrm{~h} / \mathrm{d}$ (HS) during the experimental period. The quails were then fed one of three diets: basal diet and basal diet supplemented with 100 or $200 \mathrm{mg}$ B. vulgaris root extract per kg diet. Chemical composition of B. vulgaris root extract is shown in Table 1 . The diets (Table 2) were mixed weekly in batches and stored in black plastic containers at $4^{\circ} \mathrm{C}$ to avoid photo-oxidation in airtight containers.

All quails were hatched from a large group of the parent stock that were of identical age. Each of the $2 \times 3$ factorially arranged groups was replicated in ten cages $\left(20 \times 20 \mathrm{~cm}^{2}\right.$ dimension), each consisting of three quails. During the experimental period ( 12 weeks), the birds were subjected to a $16 \mathrm{~h}$ light $-8 \mathrm{~h}$ dark cycle and offered feed and water ad libitum. 
assessment was based on the amount of enzyme required to oxidise $1 \mathrm{mmol} \mathrm{NADPH}^{(42)}$. The enzyme activities were expressed as $\mathrm{U} / \mathrm{mg}$ protein.

Western blot analyses. Accurately weighed liver tissue was homogenised in $1: 10(\mathrm{w} / \mathrm{v})$ ratio in $10 \mathrm{~mm}$-Tris- $\mathrm{HCl}$ buffer ( $\mathrm{pH} 7 \cdot 4$ ) containing $0 \cdot 1 \mathrm{~mm}-\mathrm{NaCl}, 0 \cdot 1 \mathrm{~mm}$-phenylmethylsulphonyl fluoride and $5 \mu \mathrm{m}$-soyabean (soluble powder; Sigma) as trypsin inhibitor. Tissue homogenate was centrifuged at $15000 \mathrm{~g}$ at $4^{\circ} \mathrm{C}$ for $30 \mathrm{~min}$ and the supernatant was transferred into fresh tubes. SDS-PAGE sample buffer containing $2 \% \quad \beta$-mercaptoethanol was added to the supernatant. Equal amounts of protein $(20 \mu \mathrm{g})$ were electrophoresed and subsequently transferred to nitrocellulose membrane (Schleicher and Schuell, Inc.). Nitrocellulose blots were washed twice for $5 \mathrm{~min}$ in PBS and blocked with $1 \%$ bovine serum albumin in PBS for $1 \mathrm{~h}$ prior to the application of primary antibody. Chicken antibodies against NF- $\mathrm{B}$, HSP70, Nrf2 and HO-1 (Abcam) were diluted (1:1000) in the same buffer containing 0.05\% Tween 20. The nitrocellulose membrane was incubated overnight at $4^{\circ} \mathrm{C}$ with protein antibody. The blots were washed and incubated with horseradish peroxidase-conjugated goat anti-mouse IgG (Abcam). Specific binding was detected using diaminobenzidine and $\mathrm{H}_{2} \mathrm{O}_{2}$ as substrates. Protein loading was controlled using a monoclonal mouse antibody against $\beta$-actin antibody (Sigma). Samples were analysed in quadruplicates and protein levels were determined densitometrically using an image analysis system (Image J; National Institutes of Health).

Dietary nutrients. The diets were analysed for crude protein (no. 988.05), Ca (no. 968.08) and P (no. 965.17) according to the procedures described by the Association of Official Analytical Chemists ${ }^{(43)}$. Energy and amino acid (methionine and lysine) contents were calculated from tabular values listed for the feedstuffs ${ }^{(44)}$

\section{Statistical analysis}

Data on performance parameters, oxidative stress biomarkers and proteins were analysed by two-way ANOVA using the PROC GLM procedure ${ }^{(45)}$. The linear model to test the effect of treatments on response variables was as follows: $y_{\mathrm{ijk}}=\mu+\mathrm{E}_{\mathrm{i}}+S_{\mathrm{j}}+(E \times S)_{\mathrm{ij}}+e_{\mathrm{ijk}}$, where $y=$ response variable, $\mu=$ population mean, $E=$ environmental temperature, $S=B$. vulgaris root extract supplementation and $e=$ residual error $(N(\sigma, \mu ; 0,1))$. The model also included polynomial contrast to determine changes in response variables as supplemental B. vulgaris root extract level was increased. Correlations among performance parameters, oxidative stress biomarkers and nuclear proteins were determined using the CORR procedure ${ }^{(45)}$. Statistical significance was considered at $P \leq 0 \cdot 05$.

\section{Results}

\section{Composition of Berberis vulgaris and antioxidant activity}

Table 1 lists twenty-three compounds detected in B. vulgaris root extract $(>0.05 \%$ of total ion current). B. vulgaris root extract antioxidant activity value was $60 \cdot 24$ (SD 6.27) \%. Total phenolic content was 8.92 (SD 0.55 ) mg gallic acid equivalents per $g$ extract.

\section{Performance}

Table 3 summarises performance variables. Quails exposed to HS consumed less feed $(27 \cdot 6 v \cdot 30 \cdot 2 \mathrm{~g} / \mathrm{d})$ and produced less egg (81.6 v. 92.8\%) than those reared under the $\mathrm{TN}$ environment $(P<0 \cdot 0001$ for both). Overall, there were $3 \cdot 1$ and $4.9 \%$ increases in feed intake and egg production in response to increasing dietary $B$. vulgaris root extract supplementation (linear effect; $P<0.0001$ for both). These increases were greater in the HS environment than in the TN environment (environmental temperature $\times B$. vulgaris root extract supplementation level interaction effect, $P<0.001$ for both).

\section{Hepatic malondialdehyde and antioxidant enzymes}

Heat-stressed quails had higher hepatic MDA level (2.70 $v .1 .36 \mathrm{nmol} / \mathrm{g}$ ) and lower hepatic SOD (126 v. 175), CAT (28 v. 49) and GSH-Px (10 v. 18) activities (U/mg protein) than control quails $(P<0.001$ for all). There was a linear decrease in level of MDA (by $-25.5 \%$ ) and increases in activities of SOD, CAT and GSH-Px (by 23.5, 35.4 and $55.7 \%$, respectively) as supplemental B. vulgaris root extract level in the diet increased $(P<0.001$ for all). Decrease in hepatic MDA level and increases in hepatic SOD, CAT and GHS-Px activities in response to increasing B. vulgaris root extract supplementation were more notable in the HS environment than in the TN environment (environmental temperature $\times B$. vulgaris root extract level interaction effects; $P<0.001$ for all; Table 4).

Table 3. The effects of Berberis vulgaris root extract supplementation (BV) $(\mathrm{mg} / \mathrm{kg})$ on performance of quails exposed to HS

\begin{tabular}{|c|c|c|c|c|c|c|c|c|c|c|}
\hline \multirow[b]{3}{*}{ Variable } & \multicolumn{6}{|c|}{ ET } & \multirow[b]{3}{*}{ SEM } & \multirow{2}{*}{\multicolumn{3}{|c|}{ Statistical significance $(P>F)$}} \\
\hline & \multicolumn{3}{|c|}{ TN } & \multicolumn{3}{|c|}{ HS } & & & & \\
\hline & 0 & 200 & 400 & 0 & 200 & 400 & & ET & BV & $\mathrm{ET} \times \mathrm{BV}$ \\
\hline Feed intake $(\mathrm{g} / \mathrm{d})$ & $30 \cdot 2$ & $30 \cdot 5$ & $29 \cdot 8$ & $26 \cdot 6$ & $27 \cdot 6$ & $28 \cdot 7$ & 0.2 & 0.0001 & 0.0001 & 0.001 \\
\hline Egg production (\%) & $92 \cdot 8$ & 92.5 & 93.1 & $77 \cdot 7$ & $81 \cdot 3$ & $85 \cdot 7$ & $1 \cdot 3$ & 0.0001 & 0.0001 & 0.001 \\
\hline
\end{tabular}

$\mathrm{ET}$, environmental temperature; TN, thermoneutral environment (temperature-controlled rooms at $22^{\circ} \mathrm{C}$ for $24 \mathrm{~h} / \mathrm{d}$ ); $\mathrm{HS}$, heat stress environment $\left(34^{\circ} \mathrm{C}\right.$ for $8 \mathrm{~h}$ between 09.00 and 17.00 hours followed by $22^{\circ} \mathrm{C}$ for $\left.16 \mathrm{~h} / \mathrm{d}\right)$. 


\section{Hepatic nuclear transcription factors}

Expressions of hepatic NF-кB (161.6 v. 94.1\%) and HSP70 (161.2 v. 91.4\%) were greater, whereas that of hepatic Nrf2 $(72 \cdot 1 v .113 \cdot 1 \%)$ and HO-1 (69.8 v. 112.8\%) were lower in the heat-stressed quails than the control quails $(P<0 \cdot 001$ for all). With increasing dietary $B$. vulgaris root extract supplementation, the mean expressions of hepatic NF-кB (by $-22.7 \%$ ) and HSP70 (by $-26.6 \%$ ) decreased linearly ( $P<0.001$ for both), whereas the mean expressions of hepatic Nrf2 (by $56.0 \%$ ) and HO-1 (by 38.0\%) increased linearly $(P<0.001$ for both). Decreases in hepatic NF-кB and HSP70 levels $(P<0.001$ for both) and increases in hepatic Nrf2 and HO-1 levels $(P<0.001$ for both) in response to increasing supplemental $B$. vulgaris root extract level were greater in the TN environment than in the HS environment (environmental temperature $\times B$. vulgaris root extract level interaction effects; Table 4).

\section{Correlations among oxidative stress biomarkers and} protein levels

All response variables were autocorrelated ( $P<0 \cdot 001$; Table 5). There were positive correlations between egg production and activities of antioxidant enzymes and negative correlation between egg production and hepatic MDA level. Hepatic MDA level was negatively correlated with activities of antioxidant enzymes and expressions of Nrf2 and HO-1 and positively correlated with expressions of NF- $\mathrm{B}$ and HSP70. Moreover, activities of antioxidant enzymes were negatively correlated with expressions of NF- $\mathrm{BB}$ and HSP70 and positively correlated with expressions of Nrf2 and HO-1.

\section{Discussion}

HS compromises performance and productivity through reducing feed intake, while decreasing growth rate, egg production, egg quality and feed efficiency, which lead to economic losses in poultry. HS also leads to oxidative stress associated with a reduced antioxidant status in the bird in vivo, as reflected by increased oxidative damage and lowered plasma concentrations of antioxidants. In agreement with the literature, HS caused depressions in feed intake and egg production (Table 3). Moreover, supplemental B. vulgaris extract increased feed intake and egg production at a greater extent in heat-stressed quails than control quails (Table 3). These positive impacts of $B$. vulgaris root supplementation on performance are in agreement with a previous study $^{(47,47)}$. Moreover, Kermanshahi \& Riasi ${ }^{(33)}$ reported that dried B. vulgaris fruit significantly improved haematocrit value and HDL-cholesterol in laying hens.

Cell damage occurring due to oxidative stress results in lipid peroxidation $^{(47,48)}$. This is reflected by elevated hepatic MDA level (Table 4). B. vulgaris root extract is a free radical scavenger and protects membrane stability ${ }^{(13,49)}$. Several studies reported that B. vulgaris root extract possesses antioxidant activity at different degrees in different extraction solvents ${ }^{(37,50)}$. Hanachi \& Golkho ${ }^{(50)}$ reported that the antioxidant activity of ethanol extract was the highest $(27 \cdot 26 \%)$, followed by extraction with butylated hydroxytoluene (20.29\%), methanol extract (16.80\%), vitamin E (6.68\%) and water (6.53\%). Moreover, because the extract is a pool of many named and unnamed compounds, it is always difficult to conclude the responsibility of each chemical constituent.

Living organisms facilitate the antioxidant defence system through increasing activities of detoxifying enzymes (SOD, CAT and GSH-Px (Table 4)) in order to reduce harmful effects of reactive oxygen molecules produced due to $\mathrm{HS}^{(48)}$. B. vulgaris root extract supplementation elevates the activity of SOD, CAT and GSH-Px (Table 4), probably due to its antioxidant nature. Due to limitation of literature regarding the effects of B. vulgaris root extract on the antioxidant enzymes, the present enzyme data are not comparable. However, its antioxidant effects were postulated to be linked to cytotoxicity in human liver cell lines ${ }^{(51)}$. In the present study, B. vulgaris root extract's antioxidant activity was 60.24 (SD 6.27)\%, which is in agreement with a report by Zovko-Koncić

Table 4. The effects of Berberis vulgaris root extract supplementation (BV) (mg/kg) on hepatic oxidative stress biomarkers and expressions of hepatic nuclear transcription factors in quails exposed to heat shock

\begin{tabular}{|c|c|c|c|c|c|c|c|c|c|c|}
\hline \multirow[b]{3}{*}{ Variable* } & \multicolumn{6}{|c|}{ ET } & \multirow[b]{3}{*}{ SEM } & \multirow{2}{*}{\multicolumn{3}{|c|}{ Statistical significance $(P>F)$}} \\
\hline & \multicolumn{3}{|c|}{$\mathrm{TN}$} & \multicolumn{3}{|c|}{ HS } & & & & \\
\hline & 0 & 200 & 400 & 0 & 200 & 400 & & ET & BV & $\mathrm{ET} \times \mathrm{BV}$ \\
\hline \multicolumn{11}{|l|}{ Oxidative stress biomarkers } \\
\hline MDA (nmol/g) & 1.59 & 1.32 & $1 \cdot 18$ & $3 \cdot 12$ & $2 \cdot 65$ & 2.33 & 0.09 & 0.001 & 0.001 & 0.001 \\
\hline SOD (U/mg protein) & 162 & 178 & 185 & 106 & 127 & 146 & 3.4 & 0.001 & 0.001 & 0.001 \\
\hline CAT (U/mg protein) & 42 & 51 & 55 & 23 & 28 & 33 & 1.5 & 0.001 & 0.001 & 0.001 \\
\hline GSH-Px (U/mg protein) & $14 \cdot 2$ & 18.5 & 21.9 & 7.9 & $9 \cdot 8$ & $12 \cdot 5$ & 1.03 & 0.001 & 0.001 & 0.001 \\
\hline \multicolumn{11}{|l|}{ Nuclear transcription factors } \\
\hline NF-кB & 100 & $95 \cdot 4$ & $86 \cdot 8$ & 186.5 & $163 \cdot 6$ & 134.6 & 4.5 & 0.001 & 0.001 & 0.001 \\
\hline HSP70 & 100 & 91.9 & $82 \cdot 3$ & 195.5 & 153.4 & 134.7 & $5 \cdot 1$ & 0.001 & 0.001 & 0.001 \\
\hline Nrf2 & 100 & $112 \cdot 3$ & $126 \cdot 9$ & $42 \cdot 6$ & $78 \cdot 3$ & 95.5 & $3 \cdot 8$ & 0.001 & 0.001 & 0.001 \\
\hline $\mathrm{HO}-1$ & 100 & 114.9 & $123 \cdot 6$ & $50 \cdot 2$ & 75.4 & 83.7 & $5 \cdot 0$ & 0.001 & 0.001 & 0.001 \\
\hline
\end{tabular}

$\mathrm{ET}$, environment temperature; TN, thermoneutral environment (temperature-controlled rooms at $22^{\circ} \mathrm{C}$ for $24 \mathrm{~h} / \mathrm{d}$ ); $\mathrm{HS}$, heat stress environment $\left(34^{\circ} \mathrm{C}\right.$ for $8 \mathrm{~h}$ between 09.00 and 17.00 hours followed by $22^{\circ} \mathrm{C}$ for $16 \mathrm{~h} / \mathrm{d}$ ); MDA, malondialdehyde; SOD, superoxide dismutase; CAT, catalase; GSH-Px, glutathione peroxidase; HSP70, heat shock protein 70; Nrf2, nuclear factor (erythroid-derived 2)-like 2; HO-1, haeme oxygenase-1.

* Expressions of nuclear transcription factors are percentage of control (quails reared under the TN condition and not received $B$. vulgaris root extract). 
Table 5. Pearson's correlation coefficients $(r)$ among performance variables, hepatic oxidative stress biomarkers and hepatic nuclear transcription factors*

\begin{tabular}{lcrrrrrrrr}
\hline Variables & EP & MDA & SOD & CAT & GSH-Px & NF-кB & HSP70 & Nrf2 & HO-1 \\
\hline FI (g/d) & 0.83 & -0.91 & 0.82 & 0.76 & 0.73 & -0.87 & 0.82 & 0.78 & 0.82 \\
EP (\%) & & -0.78 & 0.81 & 0.83 & 0.75 & -0.83 & 0.83 & 0.75 & 0.74 \\
MDA (nmol/g) & & & -0.82 & -0.86 & -0.83 & 0.91 & 0.92 & -0.81 & -0.91 \\
SOD (U/mg protein) & & & & 0.88 & 0.85 & -0.94 & -0.86 & 0.86 & 0.84 \\
CAT (U/mg protein) & & & & & 0.92 & -0.85 & -0.76 & 0.75 & 0.87 \\
GSH-Px (U/mg protein) & & & & & & -0.89 & 0.86 & 0.86 & 0.90 \\
NF-kB & & & & & & & 0.93 & -0.86 & -0.93 \\
HSP70 & & & & & & -0.90 & -0.85 \\
Nrf2 & & & & & & & & 0.95 \\
\hline
\end{tabular}

$\mathrm{FI}$, feed intake; EP, egg production; MDA, malondialdehyde; SOD, superoxide dismutase; CAT, catalase; GSH-Px, glutathione peroxidase; HSP70,

heat shock protein 70; Nrf2, nuclear factor (erythroid-derived 2)-like 2; HO-1, haeme oxygenase-1.

${ }^{*} P<0.001$ for correlation coefficients for all paired variables.

et $a{ }^{(13)}$. It was shown that total phenolic content of B. vulgaris increases the antioxidant activity ${ }^{(37)}$. In the present study, total phenolic content of B. vulgaris root extract was 8.92 (SD 0.55)\%. Despite not determined in the present study, other studies showed that antioxidant effects of B. vulgaris root extract could be related to its vitamin C, malic acid and tannin contents ${ }^{(50)}$. In oxidative stress induced in mice by $\mathrm{CCl}_{4}$ intoxication, Domitrović et al. ${ }^{(52)}$ reported an increase in MDA level and a decrease in SOD activity, which were ameliorated by B. vulgaris root extract. This was attributed to berberine, an isoquinoline alkaloid found in B. vulgaris root extract. Similarly, the present study demonstrated aggravated lipid peroxidation and suppressed activities of oxidative enzymes in heat-stressed quails, which were alleviated by $B$. vulgaris root extract supplementation in a dose-response manner (Table 4).

$\mathrm{NF}-\kappa \mathrm{B}$ and Nrf2 are redox-sensitive transcription factors ${ }^{(53)}$ and play a role in induction of phase II detoxifying/ antioxidant defence mechanisms to cope with oxidative stress through enhancing the expression of a number of enzymes, such as $\mathrm{NAD}(\mathrm{P}) \mathrm{H}$ quinone oxidoreductase 1, glutamate cysteine ligase, $\mathrm{HO}-1$, glutathione $S$-transferase and uricline diphosphate (UDP)-glucuronosyltransferase ${ }^{(54)}$. In addition, NF-кB is induced by various cell stress-associated stimuli, including oxidative stress. HS-induced oxidative stress increases production of reactive oxygen molecules that lead to the activation of various redox-sensitive cell signalling mol-

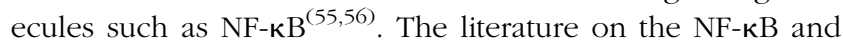
Nrf2 pathway activity in response to dietary supplementation of B. vulgaris root extract in poultry is limited. In the present study, increased expression of NF- $\mathrm{BB}$ (Table 4) and decreased expression of Nrf2 (Table 4) in heat-stressed quails could be related to their activation ${ }^{(23,24)}$ and translocation ${ }^{(30,57)}$, respectively, to overcome oxidative stress induced by HS. In the present study, the levels of berberine were $0.03 \%$. Among several alkaloids of $B$. vulgaris, berberine was considered to be responsible for most of the biological activity, such as abolished acetaldehyde-induced NF- $\mathrm{B}$ activity and cytokine production in a dose-dependent manner ${ }^{(58)}$. Liu et $a l .{ }^{(59)}$ also reported that the immunostaining of NF- $\mathrm{KB}$ was decreased and the reduced degradation of inhibitor of $\kappa \mathrm{B}$ level was partially restored after berberine treatment in alloxan-induced diabetic mice. Increased berberine-increased
HO- 1 expression is mediated by Nrf2 activation $^{(60)}$, suggesting that B. vulgaris root extract acts as modifier of signal transduction pathways to elicit cytoprotective responses.

Several studies have shown that HS triggers expression of HSP70 induction ${ }^{(25,61)}$. To our knowledge, the present study is the first to evaluate the effect of the B. vulgaris root extract supplementation on HSP in the liver of heat-stressed Japanese quail. In the present study, the HSP70 expression was much lower in quails supplemented with B. vulgaris root extract than control quails (Table 4). Other studies have ascertained the protective role of antioxidants by suppressing HSP expressions in stressed birds ${ }^{(61,62)}$.

In conclusion, B. vulgaris root extract supplementation compensated depression in performance variables (feed intake and egg production) in heat-stressed quails and alleviated oxidative stress, as reflected by lipid peroxidation and activity of antioxidant enzymes. Moreover, B. vulgaris root extract exerted antioxidant effects through inhibiting NF- $\mathrm{BB}$ and HSP70 expressions and activating Nrf 2 and $\mathrm{HO}-1$ expressions, which were activated and suppressed in the HS environment, respectively. Future studies should focus on elucidation of the effect of chemicals on the modulation of oxidative stress biomarkers and nuclear transcription proteins.

\section{Acknowledgements}

The authors thank the Veterinary Control and Research, Institute of Ministry of Agriculture, Elazig, Turkey, for providing the research facility. This work was supported by Grant N N405 625438 from the National Research Committee, Warsaw, Poland. The authors declare no conflicts of interest. The contribution of the authors is as follows: K. S., M. H. B. and N. S. were involved in the study design. N. S., C. O., M. T., J. J., A. H. and O. G. performed animal experimentation, sampling, laboratory analyses and data collection/analyses. A. H., M. H. B. and K. S. wrote the first draft of the manuscript. All authors contributed to the final version of the manuscript. K. S. had primary responsibility for the final content. This work was also supported in part by the Turkish Academy of Sciences.

\section{References}

1. Bogin E, Avidar Y, Pech-Waffenschmidt V, et al. (1996) The relationship between heat stress, survivability and blood 
composition of the domestic chicken. Eur J Clin Chem Biochem 34, 463-469.

2. Yalcin S, Ozkan S, Turkmut L, et al. (2001) Responses to heat stress in commercial and local broiler stocks. 1. Performance traits. Br Poult Sci 42, 149-152.

3. Sandercock DA, Hunter RR, Nute GR, et al. (2001) Acute heat stress-induced alterations in blood acid-base status and skeletal muscle membrane integrity in broiler chickens at two ages: implications for meat quality. Poult Sci 80, 418-425.

4. Halliwell BE \& Gutteridge JMC (1989) Lipid peroxidation: a radical chain reaction. In Free Radicals in Biology and Medicine, 2nd ed., pp. 188-218. New York, NY: Oxford University Press.

5. Sahin K \& Kucuk O (2003) Heat stress and dietary vitamin supplementation of poultry diets. Nutr Abstr Rev Ser B Livest Feeds Feed 73, 41-50.

6. Sahin K, Sahin N, Kucuk O, et al. (2009) Role of dietary zinc in heat-stressed poultry: a review. Poult Sci 88, 2176-2183.

7. Meng Q, Velalar CN \& Ruan R (2008) Effects of epigallocatechin-3-gallate on mitochondrial integrity and antioxidative enzyme activity in the aging process of human fibroblast. Free Radic Biol Med 44, 1032-1041.

8. Puthpongsiriporn U, Scheideler SE, Sell JL, et al. (2001) Effects of vitamin E and C supplementation on performance, in vitro lymphocyte proliferation, and antioxidant status of laying hens during heat stress. Poult Sci 80, 1190-1200.

9. Franchini A, Sirri F, Tallarico N, et al. (2002) Oxidative stability and sensory and functional properties of eggs from laying hens fed supranutritional doses of vitamins $\mathrm{E}$ and C. Poult Sci 81, 1744-1750.

10. Sahin N, Orhan C, Tuzcu M, et al. (2008) The effects of tomato powder supplementation on performance and lipid peroxidation in quail. Poult Sci 87, 276-283.

11. Tuzcu M, Sahin N, Karatepe M, et al. (2008) Epigallocatechin-3-gallate supplementation can improve antioxidant status in stressed quail. Br Poult Sci 49, 643-648.

12. Imanshahidi $M \&$ Hosseinzadeh $H$ (2008) Pharmacological and therapeutic effects of Berberis vulgaris and its active constituent, berberine. Phytother Res 22, 999-1012.

13. Zovko-Koncić M, Kremer D, Karlović K, et al. (2010) Evaluation of antioxidant activities and phenolic content of Berberis vulgaris L. and Berberis croatica Horvat. Food Chem Toxicol 48, 2176-2180.

14. Ivanovska N \& Philipov S (1996) Study on the anti-inflammatory action of Berberis vulgaris root extract, alkaloid fractions and pure alkaloids. Int J Immunopharmacol 18, 553-561.

15. Souto AL, Tavares JF, da Silva MS, et al. (2011) Antiinflammatory activity of alkaloids: an update from 2000 to 2010. Molecules 16, 8515-8534.

16. Kosalec I, Gregurek B, Kremer D, et al. (2009) Croatian barberry (Berberis croatica Horvat): a new source of berberine-analysis and antimicrobial activity. World J Microbiol Biotechnol 25, 145-150.

17. Bashir S, Gilani AH, Siddiqui AA, et al. (2010) Berberis vulgaris root bark extract prevents hyperoxaluria induced urolithiasis in rats. Phytother Res 24, 1250-1255.

18. Bhutada P, Mundhada Y, Bansod K, et al. (2010) Anticonvulsant activity of berberine, an isoquinoline alkaloid in mice. Epilepsy Behav 18, 207-210.

19. Fatehi M, Saleh TM, Fatehi-Hassanabad Z, et al. (2005) A pharmacological study on Berberis vulgaris fruit extract. J Ethnopharmacol 102, 46-52.

20. M Blumenthal, editor. (1998) The Complete German Commission E Monographs: Therapeutic Guide to Herbal Medicines. Boston: Integrative Medicine Communications.
21. Arayne MS, Sultana N, Bahadur SS, et al. (2007) The berberis story: Berberis vulgaris in therapeutics. PakJ Pharm Sci 20, 83-92.

22. Vaquerizas JM, Kummerfeld SK, Teichmann SA, et al. (2009) A census of human transcription factors: function, expression and evolution. Nat Rev Genet 10, 252-263.

23. Gilmore TD (2006) Introduction to NF-кB: players, pathways, perspectives. Oncogene 25, 6680-6684.

24. Nelson DE, Ihekwaba AE, Elliott M, et al. (2004) Oscillations in NF- $\mathrm{KB}$ signaling control the dynamics of gene expression. Science 306, 704-708.

25. Mahmoud KZ, Edens FW, Eisen EJ, et al. (2003) Effect of ascorbic acid and acute heat exposure on heat shock protein 70 expression by young white Leghorn chickens. Comp Biochem Physiol C Toxicol Pharmacol 136, 329-335.

26. Figueiredo D, Gertler A, Cabello G, et al. (2007) Leptin downregulates heat shock protein-70 (HSP-70) gene expression in chicken liver and hypothalamus. Cell Tissue Res 329, 91-101.

27. Murakami H, Pain D \& Blobel G (1988) 70-kD Heat shockrelated protein is one of at least two distinct cytosolic factors stimulating protein import into mitochondria. J Cell Biol 107, 2051-2057.

28. Wang S \& Edens FW (1998) Heat conditioning induces heat shock proteins in broiler chickens and Turkey poults. Poult Sci 77, 1636-1645.

29. Itoh K, Wakabayashi N, Katoh $\mathrm{Y}$, et al. (1999) Keap1 represses nuclear activation of antioxidant responsive elements by Nrf2 through binding to the amino-terminal Neh2 domain. Genes Dev 13, 76-86.

30. Yamamoto T, Suzuki T, Kobayashi A, et al. (2008) Physiological significance of reactive cysteine residues of Keap1 in determining Nrf2 activity. Mol Cell Biol 28, 2758-2770.

31. Itoh K, Chiba T, Takahashi S, et al. (1997) An Nrf2/small Maf heterodimer mediates the induction of phase II detoxifying enzyme genes through antioxidant response elements. Biochem Biophys Res Commun 236, 313-322.

32. Sahin K, Orhan C, Tuzcu M, et al. (2010) Epigallocatechin-3gallate prevents lipid peroxidation and enhances antioxidant defense system via modulating hepatic nuclear transcription factors in heat-stressed quails. Poult Sci 89, 2251-2258.

33. Kermanshahi H \& Riasi A (2006) Effect of dietary dried Berberis vulgaris fruit and enzyme on some blood parameters of laying hens fed wheat-soybean based diets. Int J Poult Sci 5, 89-92.

34. Farombi EO, Shrotriya S, Na HK, et al. (2008) Curcumin attenuates dimethylnitrosamine-induced liver injury in rats through Nrf2-mediated induction of heme oxygenase-1. Food Chem Toxicol 46, 1279-1287.

35. Jung KH, Hong SW, Zheng HM, et al. (2009) Melatonin downregulates nuclear erythroid 2-related factor 2 and nuclear factor-kappaB during prevention of oxidative liver injury in a dimethylnitrosamine model. I Pineal Res $\mathbf{4 7}$, $173-183$

36. Velázquez E, Tournier HA \& Mordujovich de Buschiazzo P (2003) Antioxidant activity of Paraguayan plants extracts. Fitoterapia 74, 91-97.

37. Motalleb G, Hanachi P, Kua SH, et al. (2005) Evaluation of phenolic content and total antioxidant activity in Berberis vulgaris fruit extract. J Biol Sci 5, 648-653.

38. Djeridane A, Yousfi M, Nadjemi B, et al. (2006) Antioxidant activity of some Algerian medicinal plants extracts containing phenolic compounds. Food Chem 97, 654-660.

39. Barim O \& Karatepe M (2010) The effects of pollution on the vitamins $\mathrm{A}, \mathrm{E}, \mathrm{C}$, beta carotene contents and oxidative stress 
of the freshwater crayfish, Astacus leptodactylus. Ecotoxicol Environ Saf 73, 138-142.

40. Spitz DR \& Oberley LW (1989) An assay for superoxide dismutase activity in mammalian tissue homogenates. Anal Biochem 179, 8-18.

41. Cohen G, Dembiec D \& Marcus J (1970) Measurement of catalase activity in tissue extracts. Anal Biochem 34, 30-38.

42. Lawrence RA \& Burk RF (1976) Glutathione peroxidase activity in selenium-deficient rat liver. Biochem Biophys Res Commun 71, 952-958.

43. AOAC (1990) Official Methods of Analysis, 15th ed. Washington, DC: Association of Official Analytical Chemists.

44. Jurgens MH (1996) Animal Feeding and Nutrition, 8th ed. Dubuque, IA: Kendall/Hunt Publishing Company.

45. SAS (2002) SAS User's Guide: Statistics (version 9). Cary, NC: Statistical Analysis System Institute, Inc.

46. Rajaian H, Jalaee J \& Aghajani A (2006) Berberis vulgaris as growth promoter in broiler chickens. Int J Poult Sci 5 , 395-397.

47. Mujahid A, Pumford NR, Bottje W, et al. (2007) Mitochondrial oxidative damage in chicken skeletal muscle induced by acute heat stress. Jpn Poult Sci 44, 439-445.

48. Tan GY, Yang L \& Fu YQ (2010) Effects of different acute high ambient temperatures on function of hepatic mitochondrial respiration, antioxidative enzymes, and oxidative injury in broiler chickens. Poult Sci 89, 115-122.

49. Tomosaka H, Chin YW, Salim AA, et al. (2008) Antioxidant and cytoprotective compounds from Berberis vulgaris (barberry). Phytother Res 22, 979-981.

50. Hanachi P \& Golkho SH (2009) Using HPLC to determination the composition and antioxidant activity of Berberis vulgaris. Eur J Sci Res 29, 47-54.

51. Hanachi P, Kua SH, Asmah R, et al. (2006) Cytotoxic effect of Berberis vulgaris fruit extract on the proliferation of human liver cancer cell line (HepG2) and its antioxidant properties. Int J Cancer Res 2, 1-9.

52. Domitrović R, Jakovac H \& Blagojević G (2011) Hepatoprotective activity of berberine is mediated by inhibition of TNF- $\alpha$, COX-2, and iNOS expression in $\mathrm{CCl}(4)$-intoxicated mice. Toxicology 280, 33-43.
53. Nair S, Li W \& Kong AN (2007) Natural dietary anti-cancer chemopreventive compounds: redox-mediated differential signaling mechanisms in cytoprotection of normal cells versus cytotoxicity in tumor cells. Acta Pharmacol Sin 28, 459-472.

54. Na HK \& Surh YJ (2008) Modulation of Nrf2-mediated antioxidant and detoxifying enzyme induction by the green tea polyphenol EGCG. Food Chem Toxicol 46, 1271-1278.

55. Surh YJ, Kundu JK, Na HK, et al. (2005) Redox-sensitive transcription factors as prime targets for chemoprevention with anti-inflammatory and antioxidative phytochemicals. J Nutr 135, 2993-3001.

56. Rahman I, Biswas SK \& Kirkham PA (2006) Regulation of inflammation and redox signaling by dietary polyphenols. Biochem Pharmacol 72, 1439-1452.

57. Nguyen T, Nioi P \& Pickett CB (2009) The Nrf2-antioxidant response element signaling pathway and its activation by oxidative stress. J Biol Chem 284, 13291-12295.

58. Hsiang CY, Wu SL, Cheng SE, et al. (2005) Acetaldehydeinduced interleukin-1beta and tumor necrosis factor- $\alpha$ production is inhibited by berberine through nuclear factor-kappaB signaling pathway in HepG2 cells. J Biomed Sci 12, 791-801.

59. Liu W, Zhang X, Liu P, et al. (2010) Effects of berberine on matrix accumulation and NF-kappa B signal pathway in alloxan-induced diabetic mice with renal injury. Eur $J$ Pharmacol 638, 150-155.

60. Chen JH, Huang SM, Tan TW, et al. (2012) Berberine induces heme oxygenase-1 up-regulation through phosphatidylinositol 3-kinase/AKT and NF-E2-related factor-2 signaling pathway in astrocytes. Int Immunopharmacol 12, 94-100.

61. Sahin N, Tuzcu M, Orhan C, et al. (2009) The effects of vitamin $\mathrm{C}$ and $\mathrm{E}$ supplementation on heat shock protein 70 response of ovary and brain in heat-stressed quail. Br Poult Sci 50, 259-265.

62. Mahmoud KZ \& Edens FW (2003) Influence of selenium sources on age-related and mild heat stress-related changes of blood and liver glutathione redox cycle in broiler chickens (Gallus domesticus). Comp Biochem Physiol B Biochem Mol Biol 136, 921-934. 